\title{
A simplified PWM technique for PV fed Five-Level Five switch Multilevel Inverter
}

\author{
Ali Qasim Hussein Algburi ${ }^{1^{*}}$, P. V. Ramana Rao ${ }^{2}$ \\ ${ }^{1}$ Research Scholar, EEE Department, Acharya Nagarjuna University, Guntur, India \\ ${ }^{2}$ Professor and HOD, EEE Department, Acharya Nagarjuna University, Guntur, India \\ *Corresponding author E-mail: engalimr4@gmail.com
}

\begin{abstract}
Bulk electrical power generation is generated using fossil fuels which emit huge pollution which is a global constraint today. Nonconventional sources of energy are the alternative energy sources for power generation. Non-conventional sources like PV (photovoltaic) system are used as power source now-a-days. Multi-level inverters (MLI) are dominating inverter circuits giving out voltage with less distortion eventually reducing voltage stress on switches and size of filter. This paper presents a MLI structure with five switches giving out five-level output from the inverter. PV system is used as source and boost converter amplifies the PV output voltage to desired value. The paper presents a simplified PWM (pulse width modulation) technique for PV fed five switch five-level inverter. The proposed system is developed and results are obtained using MATLAB/SIMULINK software. Results are presented for the system considering R-load and RL-load conditions.
\end{abstract}

Keywords:PWM; multilevel inverter; reduced switch

\section{Introduction}

Fossil fuels can generate electrical power in bulk but emission of greenhouse gases is the global issue these days with using conventional fossil fuels. To reduce the carbon gases emission from conventional power plants, renewable energy sources is the best alternative to provide stability to power system reducing the power generation from conventional plants. Photo-voltaic (PV) system [3-4], wind system, fuel-cells are examples used in renewable sources for power generation. PV system is one of the forefront generation scheme employed in major. PV cell is a simple P-N junction layer to produce potential barrier between the two layers. Photon from the light energy when absorbed by the charge carriers in PV cell, electrons starts flowing and giving rise to current flow [5-6].

PV generates DC kind of source and requires an inverter to feed load. General two-level inverters suffer from high distortion in output voltage. Two-level inverter impresses high stress on switching devices. This disadvantages leads to development of multi-level inverters [7-10]. As the level of output from inverter is increased, harmonic distortion is reduced and also the stress across switch reduces reducing the switching losses.

This paper presents a MLI structure with five switches giving out five-level output from the inverter. PV system is used as source and boost converter amplifies the PV output voltage to desired value. Figure 1 illustrates the block representation of proposed concept PV fed MLI. The paper presents a simplified PWM (pulse width modulation) technique for PV fed five switch five-level inverter. The proposed system is developed and results are obtained using MATLAB/SIMULINK software. Results are presented for the system considering R-load and RL-load conditions.

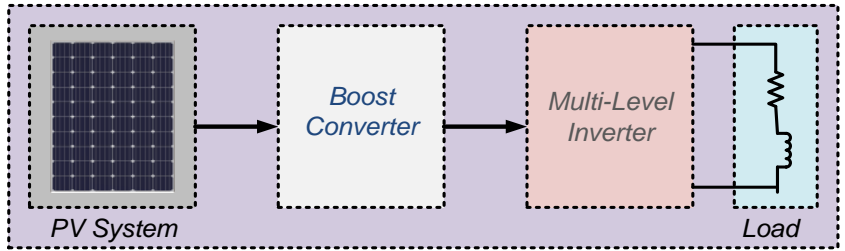

Fig. 1: Block representation of PV fed MLI

\section{PV Fed Multi-Level Inverter}

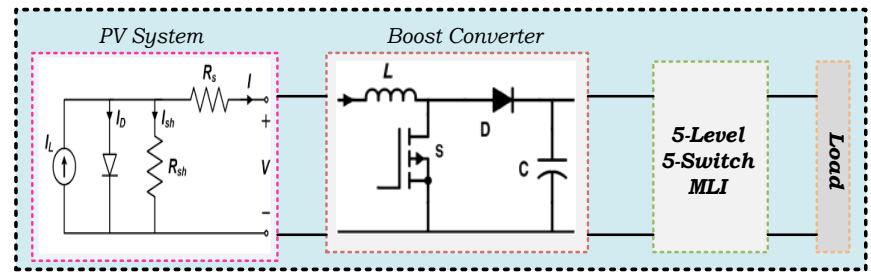

Fig. 2: PV system (with boost converter) fed MLI

Figure 2 illustrates the PV system (with boost converter) fed MLI. Solar energy when irradiated on solar panel, the PN layers in solar panels absorb the photon energy from solar energy and current flows breaking the barrier between PN junctions allowing voltage to present across PV output. The PV system generally produces low voltage DC output which needs additional converter to stepup the voltage level. Boost converter steps up the voltage level of PV output to required level. Conventional boost converter consists of passive components like $\mathrm{L}, \mathrm{C}$ for boost operation and the charging and discharging are controlled using a controlled switch. The output of boost converter is fed to multi-level inverter which pro- 
duces multiple leveled outputs reducing the inverter output voltage and current distortion.

\section{A. Design of Boost Converter}

Input voltage $\left(\mathrm{V}_{\text {in }}\right)=100 \mathrm{~V}, \mathrm{~V}_{\mathrm{O}}=400 \mathrm{~V}$

Output power $\left(\mathrm{P}_{\mathrm{O}}\right)=20 \mathrm{~kW}, \mathrm{~F}=20 \mathrm{kHz}$

$\mathrm{O} / \mathrm{P}$ current $\mathrm{I}_{\mathrm{O}}=\frac{P}{V_{O}}=\frac{20 \times 10^{3}}{400}=50 \mathrm{Amps}$

$\mathrm{O} / \mathrm{P}$ resistance $\mathrm{R}=\frac{V_{O}}{I_{O}}=\frac{400}{50}=8 \Omega$

$\frac{V_{O}}{V_{\text {in }}}=\frac{1}{1-D}$

$\frac{400}{100}=\frac{1}{1-D}$

$1-\mathrm{D}=0.25$

$\mathrm{D}=1-0.25=0.75$

$\therefore$ Duty ratio $\mathrm{D}=0.75$

$\mathrm{V}_{\mathrm{O}} \mathrm{I}_{\mathrm{O}}=\mathrm{V}_{\text {in }} \mathrm{I}_{\text {in }}$

$\mathrm{I}_{\text {in }}=\frac{400 \times 50}{100}$

$\mathrm{I}_{\text {in }}=200 \mathrm{Amps}$

Ripple current $\Delta \mathrm{I}=5 \%$ of $\mathrm{I}_{\text {in }}$

$\Delta \mathrm{I}=\frac{5}{100} \times 200=10 \mathrm{Amps}$

Ripple voltage $\Delta V_{C}=5 \%$ of Output voltage

We have

$$
\Delta \mathrm{V}_{\mathrm{C}}=\frac{5}{100} \times 400=20 \text { volts }
$$

$\Delta \mathrm{I}=\frac{V_{i n \times D}}{f \times L}$

$\mathrm{L}=\frac{V_{\text {in }} \times D}{f \times \Delta \mathrm{I}}$

$\mathrm{L}=\frac{100 \times 0.75}{20 \times 10^{3} \times 10}$

$\mathrm{L}=0.375 \times 10^{-3} \mathrm{H}$

$\therefore \mathrm{L}=0.375 \mathrm{mH}$

Let $\mathrm{I}_{0}=\mathrm{I}_{\mathrm{C}}=\frac{V_{O}}{R}=\frac{\mathrm{C}_{\mathrm{d}} \Delta \mathrm{V}_{\mathrm{C}}}{d t}$

$\mathrm{C}=\frac{\mathrm{V}_{\mathrm{O}} \times D}{R \times \Delta \mathrm{V}_{\mathrm{C}} \times f}=\frac{400 \times 0.75}{8 \times 20 \times 20 \times 10^{3}}$

$\therefore \mathrm{C}=93.7 \mu \mathrm{F}$

\section{PV fed Five Switch Five-Level Inverter}

Figure 3 shows the five-level multilevel inverter with five switches. In this case the circuit consists of two voltage sources of same magnitude. Four IGBT switches (S1 to S4) are used and one bidirectional switch (S5) is used at source side.

\section{A. Five switch Five-level inverter topology}

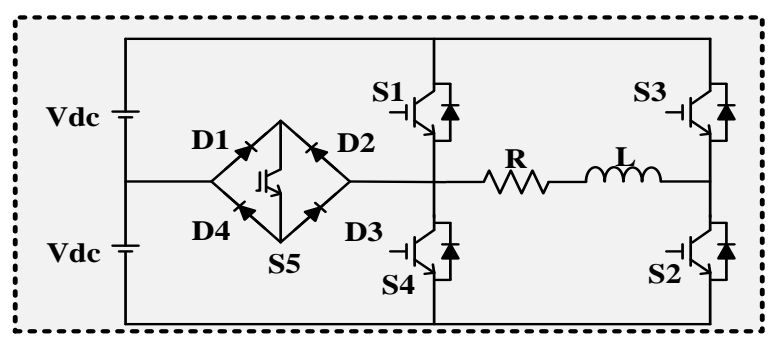

Fig. 3: 5-level multilevel inverter with five switches

Table 1: Switching pattern

\begin{tabular}{|c|c|c|c|c|c|}
\hline \multicolumn{7}{|c|}{ Table 1: Switching pattern } \\
\hline $\begin{array}{c}\text { Voltage } \\
\text { levels }\end{array}$ & \multicolumn{7}{|c|}{ Switching Sequence } \\
\cline { 2 - 6 } $\mathbf{2 V}_{\mathbf{d c}}$ & $\mathbf{S}_{\mathbf{1}}$ & $\mathbf{S}_{\mathbf{2}}$ & $\mathbf{S}_{\mathbf{3}}$ & $\mathbf{S}_{\mathbf{4}}$ & $\mathbf{S}_{\mathbf{5}}$ \\
\hline $\mathbf{V}_{\mathbf{d c}}$ & 0 & 1 & 0 & 0 & 0 \\
\hline $\mathbf{0}$ & 0 & 1 & 0 & 0 & 1 \\
\hline$-\mathbf{V}_{\mathbf{d c}}$ & 0 & 0 & 1 & 0 & 1 \\
\hline$-\mathbf{2} \mathbf{V}_{\mathbf{d c}}$ & 0 & 0 & 1 & 1 & 0 \\
\hline
\end{tabular}

Table 1 gives the switching sequence for 5-level multilevel inverter with five switches. From the table it is clearly understood that which switches are operating for a particular output voltage level. ' 0 ' indicates the switch OFF condition and ' 1 ' indicates the switch ON condition.

\section{B. PV Fed five switch five-level inverter}

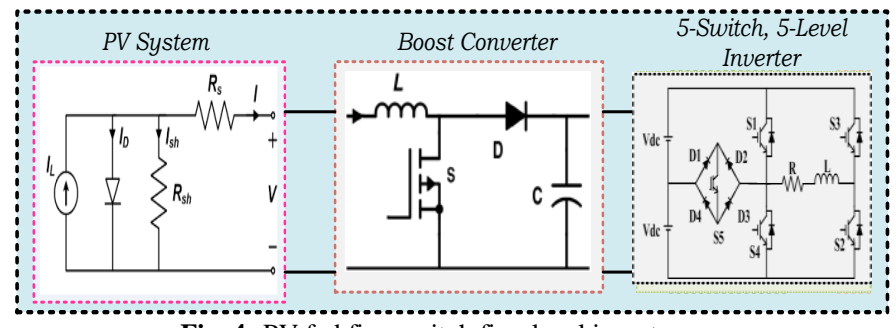

Fig. 4: PV fed five-switch five-level inverter

Figure 4 illustrates PV fed five-switch five-level inverter. The input to the topology of five-switch five-level inverter is boost output. PV output is boosted using boost converter and the output of boost converter is fed to five-level five switch inverter. The terminal voltage across load gives five-level alternating output voltage. Boost converter is operated $\mathrm{n}$ closed-loop mode. The output capacitance voltage of boost converter is split across two capacitors of inverter. Two capacitors share the voltage and generate five-level output voltage across load by sequential switching as give in table-1.

\section{Control logic for five switch five-level inverter}

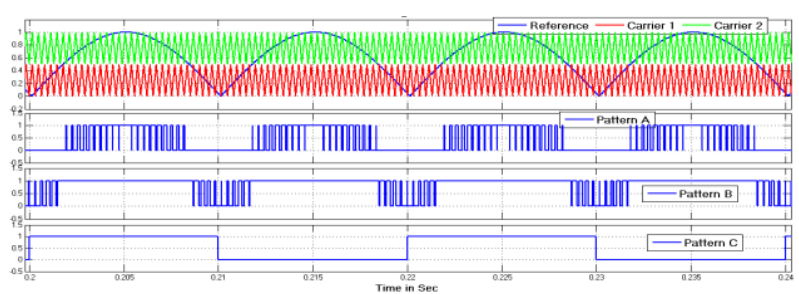

Fig. 5: PWM pattern

Several modulation strategies are used in multi-level inverters for several applications to control the output voltage waveform. Generally, PWM strategies are comprised into three objectives, such as fundamental switching frequency PWM technique, carrier based PWM technique, space vector PWM technique. Out of all, the multi-carrier based PWM techniques are more popular because of low complex function when the more number of output voltage levels. This paper employs the new multi-carrier based pulse width-modulation (PWM) technique consisted of one reference signal $\left(\mathrm{V}_{\text {ref }}\right)$ were compared with a dual carrier signals $\left(\mathrm{V}_{\text {carl }}\right.$, $\mathrm{V}_{\text {car2 }}$ ). All the carriers had high switching frequency with a little difference in peak magnitude which is vertically disposed. The carrier signals are compared with dual carrier signals to generate the switching states A and B.

These switching states A and B are controlled by additional pulse generated switching state $\mathrm{C}$. The generation of optimal pulses to the proper switches is defined by mathematical notation which is depicted in Eqn. (1). The PWM pattern of producing states of the proposed 5-level five-switch MLI is depicted in Fig.5.

$S 1=A \cdot C$

$S 2=(\bar{B} \cdot \bar{C})+C$

$S 3=B \cdot \bar{C}$

$S 4=(A \cdot \bar{C})+(\bar{B} \cdot \bar{C})+(\bar{B} \cdot C)$

$S 5=\bar{A} \cdot B$ 


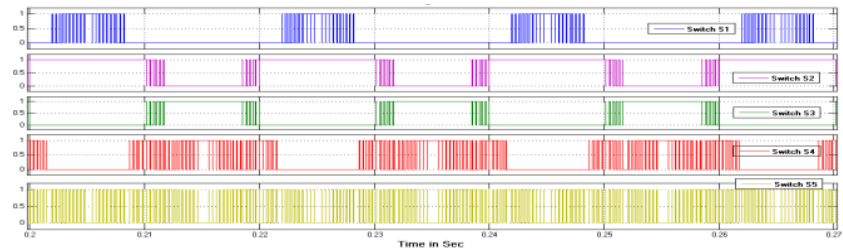

Fig. 6: Switching pattern

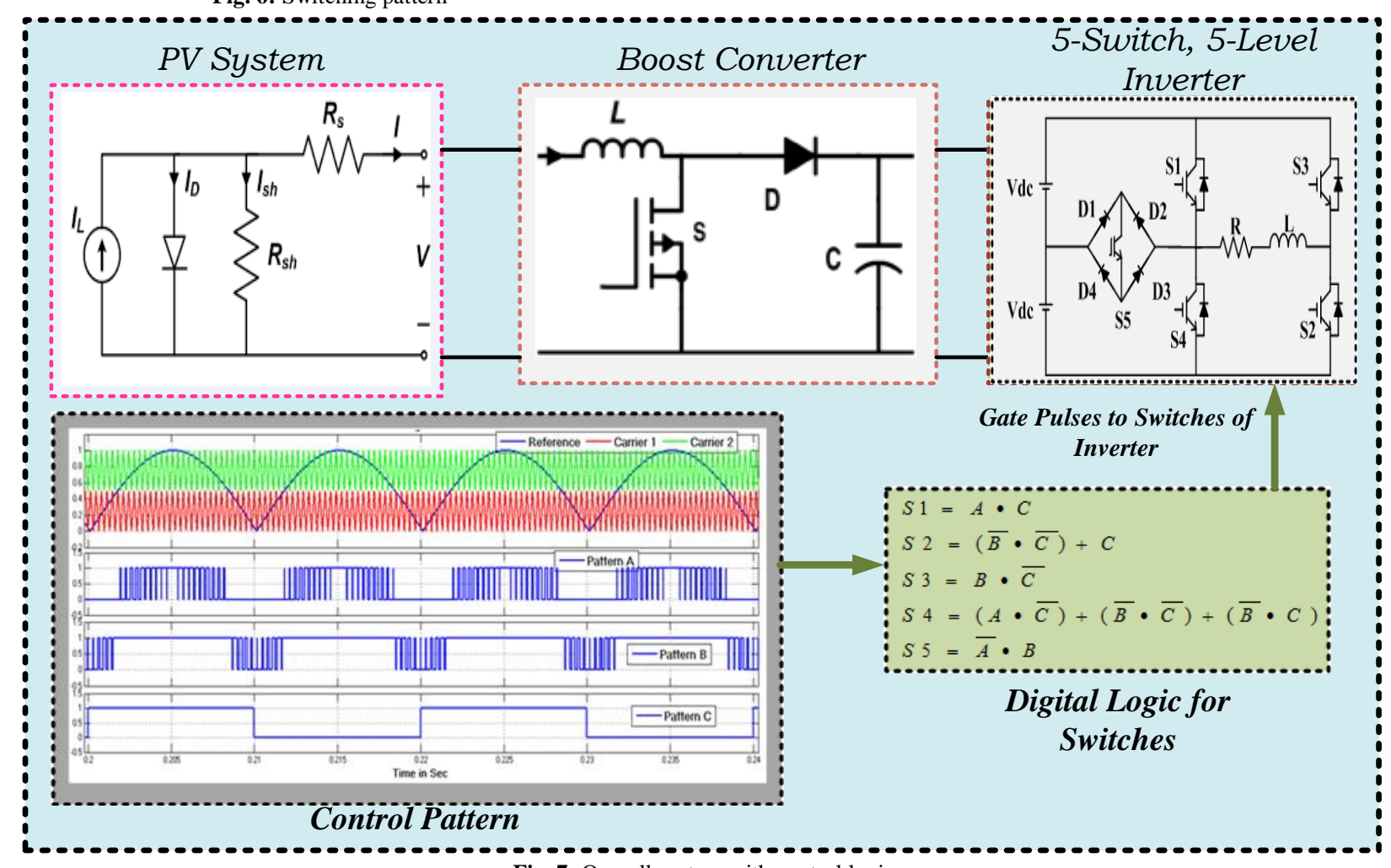

Fig. 7: Overall system with control logic
Pattern A, B, C operated logically as in (1) produces switching pulses as shown in figure 6 respective switches of five-level fiveswitch inverter.

The digital logic for producing pulses to five switches in proposed five-level inverter is shown in (1). The overall system with PV fed five-level five-switch inverter with control logic is shown in figure 7.

\section{Result Analysis}

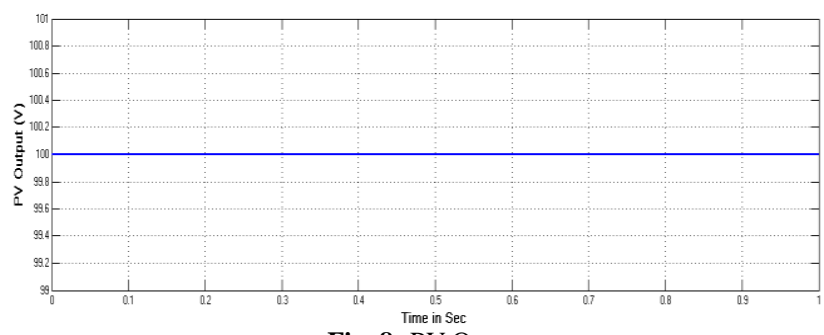

Fig. 8: PV Output

Figure 8 illustrates output voltage of PV system. PV system gives out $100 \mathrm{~V}$ constant output voltage. The solar output remains constant over a period of time.

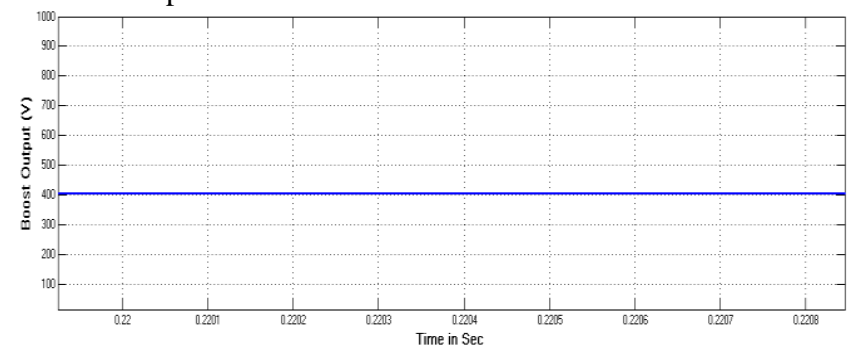

Fig. 9: Boost Output voltage

Figure 9 shows the output voltage of boost DC-DC converter. Output voltage of PV system is $100 \mathrm{~V}$ and the $100 \mathrm{~V}$ is fed as input to boost converter. The boost converter steps up the level of voltage to $400 \mathrm{~V}$ at the converter output as shown in figure.

\section{A. R-Load Condition}

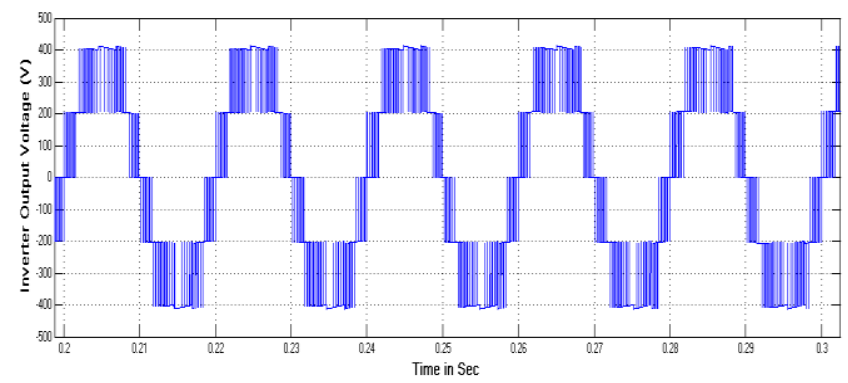

Fig. 10: Inverter Output Voltage

Figure 10 shows the output voltage of five-switch five-level inverter. The output voltage consists of five levels with peak $400 \mathrm{~V}$.

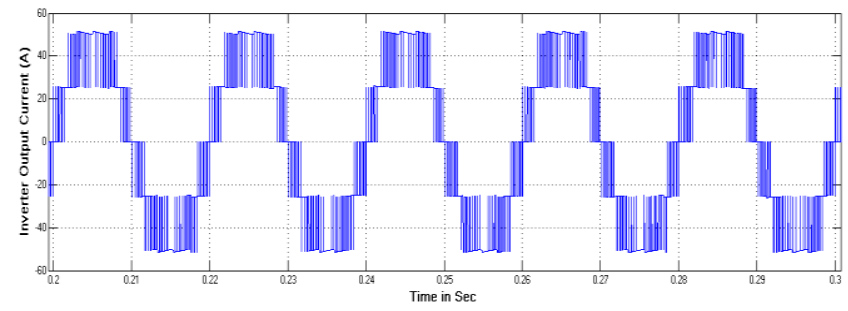

Fig. 11: Inverter Output Current

Figure 11 shows the output current of five-switch five-level inverter. The output current consists of five levels with peak 50A. 


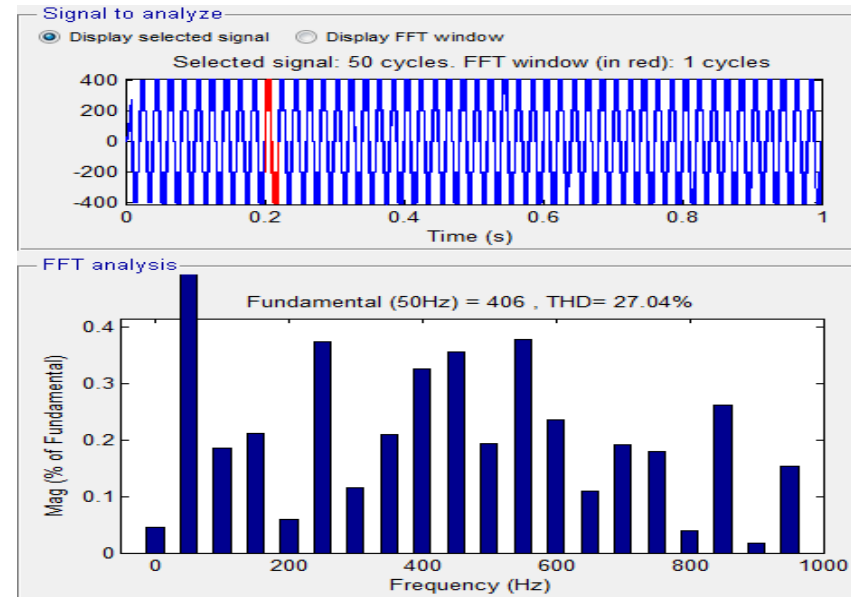

Fig. 12: THD in Voltage

Figure 12 illustrates the FFT window of harmonic distortion in inverter output voltage. Inverter output is five leveled output consisting of $27.04 \%$ distortion with respect to fundamental component.

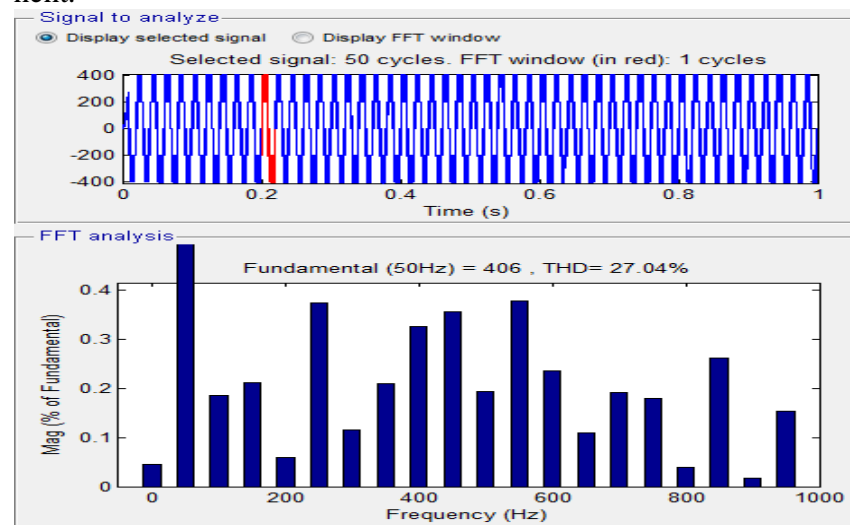

Fig.13: THD in Current

Figure 13 illustrates the FFT window of harmonic distortion in inverter output current. Inverter output is five leveled output consisting of $27.04 \%$ distortion with respect to fundamental component.

\section{B. RL-Load Condition}

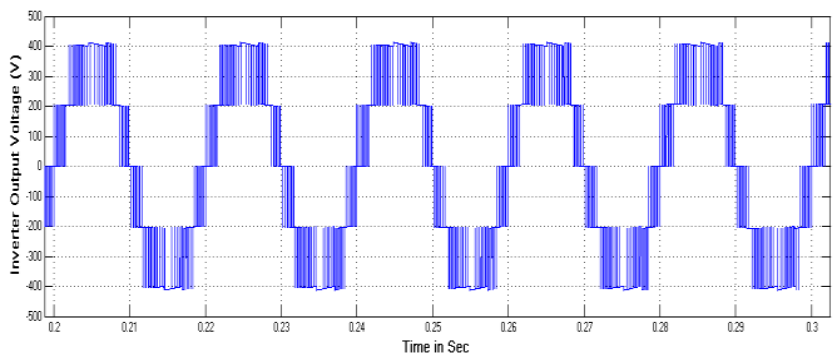

Fig. 14: Inverter Output Voltage

Figure 14 shows the output voltage of five-switch five-level inverter. The output voltage consists of five levels with peak $400 \mathrm{~V}$ with RL-load condition.

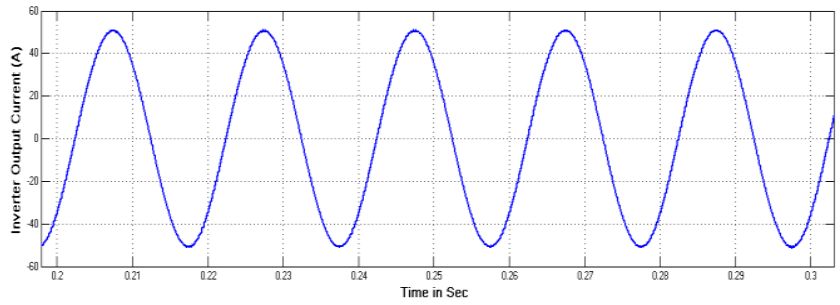

Fig.15: Inverter Output Current
Figure 15 shows the output current of five-switch five-level inverter with RL-load condition. The output current is sinusoidal with peak 50A. with RL-load, output current is smoothened by load inductor and hence load current is undistorted.

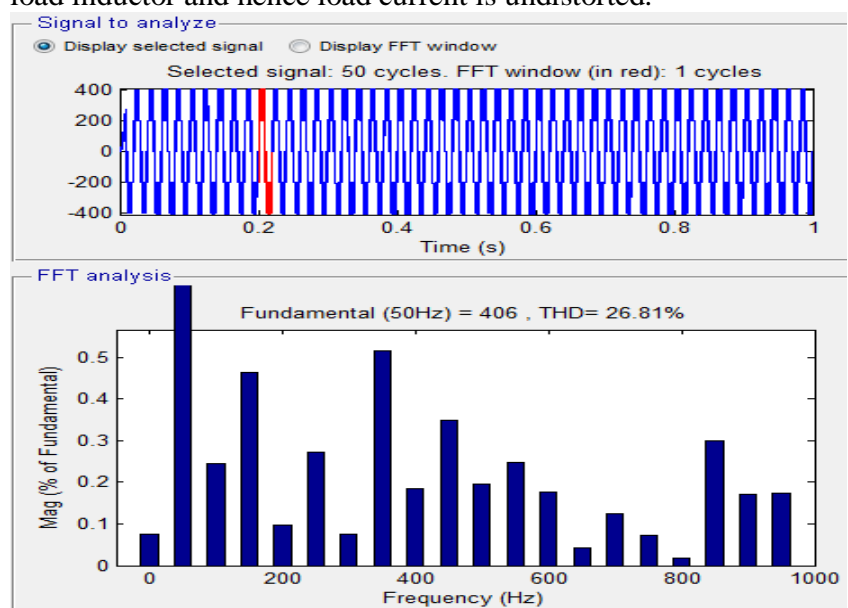

Fig. 16: THD in Voltage

Figure 16 illustrates the FFT window of harmonic distortion in inverter output voltage. Inverter output is five leveled output consisting of $26.81 \%$ distortion with respect to fundamental component.

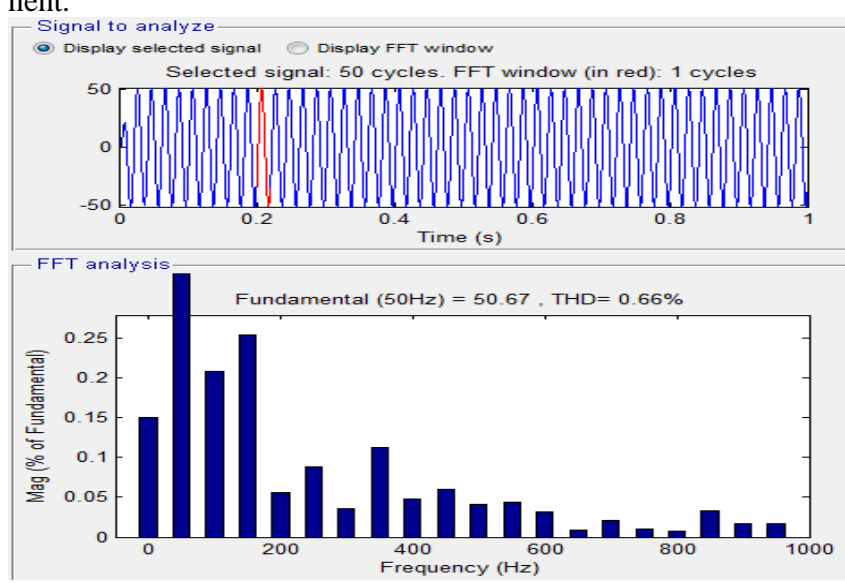

Fig. 17: THD in Current

Figure 17 illustrates the FFT window of harmonic distortion in inverter output current. Inverter output consists of $0.66 \%$ distortion with respect to fundamental component replicating nearer pure sinusoidal.

Table 2 illustrates harmonic distortion analysis with different loading conditions.

Table 2: Harmonic distortion analysis

\begin{tabular}{|c|c|c|}
\hline Load Condition & Inverter Voltage THD & Inverter Current THD \\
\hline R-Load & $27.04 \%$ & $27.04 \%$ \\
\hline RL-Load & $26.81 \%$ & $0.66 \%$ \\
\hline
\end{tabular}

\section{Conclusion}

Green energy solutions are of major interest in this era. This paper presents a MLI structure with five switches giving out five-level output from the inverter. PV system supplies the system through boost converter. Design of boost converter is depicted. The paper presents a simplified PWM (pulse width modulation) technique for PV fed five switch five-level inverter. Results are presented for the system considering R-load and RL-load conditions. Harmonic distortion analysis is tabulated and illustrates the harmonics in 
inverter current is reduced with RL-load condition, while THD in inverter voltage remains almost same. PV output and boost converter output are shown in result analysis. Digital control logic is explained in detail and switching pattern is shown.

\section{References}

[1] R. Sekar, D. S. Suresh and H. Naganagouda, "A review on power electronic converters suitable for renewable energy sources," 2017 International Conference on Electrical, Electronics, Communication, Computer, and Optimization Techniques (ICEECCOT), Mysuru, 2017, pp. 501-506.

[2] Sunar, C. Nithya and J. P. Roselyn, "Study of intelligent MPPT controllers for a grid connected PV system," 2017 IEEE International Conference on Intelligent Techniques in Control, Optimization and Signal Processing (INCOS), Srivilliputhur, 2017, pp. 1-6.

[3] G. Petrone, G. Spagnuolo, R. Teodorescu, M. Veerachary, M. Vitelli, "Reliability issues in photovoltaic power processing systems", IEEE Trans. Ind. Electron., vol. 55, no. 7, pp. 2569-2580, Jul. 2008.

[4] G. Masagani and V. Kandhagatla, "Renewable energy through hydro power - A substantial source: Preventing global warming from becoming a planetary catastrophe may take something even more drastic than renewable energy, superefficient urban design, and global carbon taxes Jamais Cascio," 2017 IEEE International Conference on Power, Control, Signals and Instrumentation Engineering (ICPCSI), Chennai, India, 2017, pp. 1425-1430.

[5] E. H. H. Kure, S. Maharjan, S. Gjessing and Y. Zhang, "Optimal battery size for a green base station in a smart grid with a renewable energy source," 2017 IEEE International Conference on Smart Grid Communications (SmartGridComm), Dresden, 2017, pp. 115-121

[6] J. P. Patel and S. K. Joshi, "Harmonic stability of grid connected renewable energy source — A case study," 2017 52nd International Universities Power Engineering Conference (UPEC), Heraklion, 2017, pp. 1-6.

[7] F. Eroglu, A. O. Arslan, M. Kurtoglu and A. M. Vural, "Generalized adaptive phase-shifted PWM for single-phase seven-level cascaded H-bridge multilevel inverters," 2018 5th International Conference on Electrical and Electronic Engineering (ICEEE), Istanbul, Turkey, 2018, pp. 7-12

Sharma and K. S. Kashyap, "Harmonic minimization in multilevel inverters using numerical series technique," 2017 IEEE International Conference on Power, Control, Signals and Instrumentation Engineering (ICPCSI), Chennai, India, 2017, pp. 2095-2103.

[8] S. S. Tomar, N. Agrawal and P. Bansal, "Various modulation techniques in symmetrical multilevel inverters," 2017 International Conference on Energy, Communication, Data Analytics and Soft Computing (ICECDS), Chennai, India, 2017, pp. 1322-1327.

Hemanth Kumar Raju, K. S. S. P. Raju, G. Harish Kumar Varma and K. Vaisakh, "A novel multilevel inverter configuration with reduced components," 2017 IEEE International Conference on Power, Control, Signals and Instrumentation Engineering (ICPCSI), Chennai, India, 2017, pp. 934-939 